\title{
Induction of apoptosis in thecal/interstitial cells: action of transforming growth factor (TGF) $\alpha$ plus TGF $\beta$ on bcl-2 and interleukin-1 $\beta$-converting enzyme
}

\author{
A Foghi ${ }^{1}$, K J Teerds ${ }^{2}$, H van der Donk ${ }^{3}$, N C Moore ${ }^{4}$ and \\ J Dorrington ${ }^{1}$
}

${ }^{1}$ Banting and Best Department of Medical Research, University of Toronto, Toronto, Canada, ${ }^{2}$ Department of Cell Biology and Histology, Faculty of Veterinary Medicine, Utrecht, The Netherlands, ${ }^{3}$ Department of Cell Biology, Faculty of Medicine, Utrecht, The Netherlands and ${ }^{4}$ CCRIS, University of Birmingham, Birmingham, UK

(Requests for offprints should be addressed to J Dorrington)

\begin{abstract}
Follicular atresia is characterized by the initial rapid loss of granulosa cells by apoptosis, followed by the loss of thecal cells at a slower rate. We have previously shown that treatment of subconfluent cultures of thecal/interstitial cells $(\mathrm{T} / \mathrm{I})$ with transforming growth factor (TGF) $\alpha$ plus TGF $\beta$ caused chromatin condensation and internucleosomal fragmentation characteristic of apoptosis, whereas in the presence of either TGF $\alpha$ or TGF $\beta$ alone the cells remained healthy. In this study we have examined the effect of TGF $\alpha$ and TGF $\beta$ alone and in combination on the levels of mRNA encoding bcl-2 and interleukin$1 \beta$-converting enzyme (ICE) in $\mathrm{T} / \mathrm{I}$ cells using a semi-quantitative reverse transcription-polymerase chain reaction (RT-PCR) assay. Bcl-2, a cell survival gene, has been implicated in regulating the balance between cell proliferation and cell death in physiological processes. ICE, the homolog of the C. elegans cell death gene, ced-3, is also involved in apoptotic signal transduction. The levels of mRNA encoding specific PCR products for bcl-2 (430 bp) and ICE (453 bp) were amplified from T/I cell cDNA. Untreated T/I cells and TGF $\alpha$ - or TGF $\beta$-treated
\end{abstract}

cells contained comparable levels of bcl-2 mRNA. Treatment of T/I cells with TGF $\alpha$ plus TGF $\beta$ significantly decreased the levels of bcl-2 mRNA expression. TGF $\alpha$ plus TGF $\beta$ caused a significant decrease in bcl-2 mRNA levels within $3 \mathrm{~h}$ of treatment of T/I cells, followed by a progressive decline to $10 \%$ of control levels after $24 \mathrm{~h}$ of treatment. In contrast, in control T/I cells, the levels of ICE mRNA were low. TGF $\alpha$ plus TGF $\beta$ caused a progressive increase in ICE mRNA, reaching levels 2- and 3 -fold higher than control cells after 5 and $7 \mathrm{~h}$ respectively. DNA analysis showed that DNA fragmentation, indicative of apoptosis, occurred after $10 \mathrm{~h}$ of treatment with TGF $\alpha$ plus TGF $\beta$. These studies demonstrated that treatment of T/I cells with TGF $\alpha$ plus TGF $\beta$ influenced gene expression of bcl-2 and ICE prior to the time at which DNA fragmentation was observed. We propose that the gene products of bcl-2 and ICE are involved in the apoptotic signal transduction pathway induced by TGF $\alpha$ plus TGF $\beta$ in $\mathrm{T} / \mathrm{I}$ cells.

Journal of Endocrinology (1998) 157, 489-494

\section{Introduction}

Of the cohorts of follicles that develop throughout reproductive life, only a small proportion ovulate and the majority undergo atresia (Byskov 1978, Hirshfield 1991). Atresia is the process by which follicles that are not selected to ovulate are eliminated from the ovary. The balance that is established between the growth of healthy follicles and the loss of follicles by atresia maintains a constant cell mass and homeostasis of the ovary throughout reproductive life. Atresia is an active and strictly regulated process, characterized by the initial rapid loss of granulosa cells by apoptosis, followed by the loss of thecal cells at a slower rate (Hughes \& Goespe 1991, Tilly et al. 1991,
Logothetopoulos et al. 1995). Evidence from studies on rat, porcine and avian ovaries indicates that apoptosis is the underlying mechanism by which not only granulosa cells but also thecal cells are eliminated from atretic follicles in vivo (Tilly et al. 1991, 1992, Palumbo \& Yeh 1994). Little is known about the mechanism by which thecal cells are eliminated. In a recent study we have shown that subconfluent cultures of thecal/interstitial (T/I) cells treated with transforming growth factor (TGF) $\alpha$ plus TGF $\beta$ rounded up and detached from the culture dish, whereas, in the presence of either TGF $\alpha$ or TGF $\beta$ alone, the morphological appearances of the cells remained healthy (Foghi et al. 1996a). Chromatin condensation and internucleosomal fragmentation, indicative of cell loss by 
apoptosis, were observed in TGF $\alpha$ - plus TGF $\beta$-treated $\mathrm{T} / \mathrm{I}$ cells by nucleic acid staining and fluorescence microscopy (Foghi et al. 1996a). The objective of this study was to identify molecular mechanisms involved in the induction of apoptosis in T/I cells. $\mathrm{Bcl}-2$ is an anti-apoptotic proto-oncogene and is a homolog of the C. elegans gene, ced-9 (Barinaga 1994, Hengartner \& Horvitz 1994, Schwartz \& Osborne 1994, Li et al. 1995). Bcl-2 functions as a dominant suppressor of apoptosis in a wide variety of cell types and is negatively regulated by multiple and diverse apoptotic stimuli such as radiation, hyperthermia, growth factor withdrawal, glucocorticoids, and chemotherapeutic agents (Hockenberg et al. 1993, Knudson et al. 1995, Linette et al. 1995). Interleukin-1ßconverting enzyme (ICE) is a mammalian cysteine protease and a homolog of the C. elegans cell death gene, ced-3. It plays a key role in a variety of physiological and pathological processes involving programmed cell death (Kumar 1995, Kumar \& Harvey 1995). We have explored the possibility that TGF $\alpha$ plus TGF $\beta$ regulate gene expression of bcl-2 and ICE in T/I cells undergoing apoptosis.

\section{Materials and Methods}

\section{Animals}

Immature Wistar rats, 22 days of age, were obtained from Charles River Canada (Montreal, Canada) and maintained under conditions of controlled light and temperature.

\section{Isolation and culture of $T / I$ cells}

$\mathrm{T} / \mathrm{I}$ cells were isolated from 25-day-old rats by the method of Lobb et al. (1988) with modifications (Foghi et al. 1996a). Cells were plated at a density that generated subconfluent cultures after $24 \mathrm{~h}$ under control conditions. Two hours after plating, the medium was removed and the attached cells were gently washed twice in serum-free medium. Serum-free medium was added, and the cultures were treated immediately after washing with TGF $\alpha$ (10 ng/ml; Vector Biosystems, Toronto, Canada) and/or TGF $\beta$ (10 ng/ml; purified from porcine platelets, R\&D Systems Inc., Minneapolis, MN, USA). After 24 h under control conditions the cultures contained approximately $3 \times 10^{5}$ cells/well. The $\mathrm{T} / \mathrm{I}$ cell cultures prepared as described above have been characterized morphologically and biochemically in previous studies (Skinner et al. 1987, Bendell \& Dorrington 1988, Lobb et al. 1988).

\section{RNA extraction}

The method used for RNA extraction was a modification of that of Chomczynski \& Sacchi (1987). Briefly, cells were lysed in a solution containing $4 \mathrm{M}$ guanidinium isothiocyanate (Gibco BRL, Burlington, Ontario, Canada), 0.5\% sarcosyl (Fisher Scientific, Unionville, Ontario, Canada), $25 \mathrm{mM}$ sodium citrate (Fisher Scientific) and $100 \mathrm{mM} \beta$-mercaptoethanol $(200 \mu \mathrm{l}$ per well). Lysates from three wells were pooled into microcentrifuge tubes, giving duplicate RNA samples for each treatment. RNA was extracted from the lysates by addition of $60 \mu \mathrm{l} 2 \mathrm{M}$ sodium acetate $(\mathrm{pH} 4 \cdot 0), 600 \mu \mathrm{l}$ water-saturated phenol (Gibco BRL) and $135 \mu \mathrm{l}$ chloroform:isoamyl alcohol (24:1), with tubes vortexed between each addition. Samples were then kept on ice for $15 \mathrm{~min}$, centrifuged at $13000 \mathrm{~g}$ for $5 \mathrm{~min}$, and the aqueous phases containing the RNA were then transferred to fresh microcentrifuge tubes. RNA was precipitated by addition of $600 \mu \mathrm{l}$ isopropanol, and incubated at $-20^{\circ} \mathrm{C}$ for at least $2 \mathrm{~h}$. After collection of RNA by centrifugation at 13000 $\boldsymbol{g}$ for $10 \mathrm{~min}$, pellets were washed with $1 \mathrm{ml} \mathrm{70 \%} \mathrm{ethanol,}$ and allowed to dry. RNA was redissolved in $50 \mu \mathrm{l}$ nuclease-free water (Promega Corporation, Madison, WI, USA), and RNA was reprecipitated by addition of $5 \mu \mathrm{l}$ $3 \mathrm{M}$ sodium acetate and $125 \mu \mathrm{l}$ ethanol, followed by storage at $-20{ }^{\circ} \mathrm{C}$ for at least $2 \mathrm{~h}$. RNA was again collected by centrifugation at $13000 \mathrm{~g}$ for $10 \mathrm{~min}$, pellets were washed with $1 \mathrm{ml} \mathrm{70 \%} \mathrm{ethanol,} \mathrm{and} \mathrm{allowed} \mathrm{to} \mathrm{dry.}$ Final pellets of RNA were dissolved in $50 \mu \mathrm{l}$ nuclease-free water, and the concentration of RNA in each sample was carefully determined in duplicate by spectrophotometry.

\section{Reverse transcriptase-polymerase chain reaction (RT-PCR) assay}

After determination of the linear range of the assay (unpublished data), cDNA was synthesized from each sample in duplicate, using $200 \mathrm{ng}$ total RNA. PCR was carried out using cDNA equivalent to $60 \mathrm{ng}$ total RNA. Each PCR run also included a blank, in which cDNA was replaced with water, and also a 'no-RT' control sample to allow detection of contamination of stock solutions. The reactions containing cDNA, specific primers and $1 \mu \mathrm{Ci}$ $\left[\alpha-{ }^{32} \mathrm{P}\right] \mathrm{dCTP}$ (DuPont Canada Inc., Mississauga, Ontario, Canada) were performed under mineral oil, and PCR was carried out using a commercial thermocycler (Perkin Elmer Cetus, DNA Thermal Cycler). A hot start was employed to avoid primer-dependent PCR artifacts: tubes were heated to $97^{\circ} \mathrm{C}$ for $5 \mathrm{~min}$ to denature DNA, and then held at $79^{\circ} \mathrm{C}$ while Taq polymerase was added. Denaturing was carried out at $94^{\circ} \mathrm{C}$ for $1 \mathrm{~min}$, annealing at $58{ }^{\circ} \mathrm{C}$ and $60^{\circ} \mathrm{C}$ for bcl-2 and ICE respectively for $1 \mathrm{~min} 20 \mathrm{~s}$, and extension at $72^{\circ} \mathrm{C}$ for $2 \mathrm{~min}$. PCR was carried out for 35 cycles. An additional extension step $\left(72{ }^{\circ} \mathrm{C}\right.$ for $8 \mathrm{~min}$ ) was added after the last cycle, and tubes were held at $6{ }^{\circ} \mathrm{C}$ at the end of the program.

Primers used for amplification of the bcl-2 cDNA were 5'-CCT GTG CCA CCA TGT GTC CAT-3', and 5'-GCT GAG AAC AGG GTC TTC AGA GAC-3'. The specificity for the bcl-2 PCR product correlated with 
that of Tao et al. (1994). The primers used for ICE PCR were 5'-AGG TCA ACA TCA GCT CCG AC-3', corresponding to position 554 on bottom strand (20 out of 20 positions) and $5^{\prime}$-CCT GAA CCA GGA AGA GAT GG-3', hybridized to position 102 on top strand (20 out of 20 positions). Complete cDNA sequence of ICE was retrieved from NCBI with accession code U14647 (1209 bp). Analysis for ICE PCR product was complemented by sequence analysis combined with restriction endonuclease digestion/mapping of the product. Restriction enzyme Bbs I (BioLabs, New England) was used to cleave the product at $235 \mathrm{bp}$ restriction site generating two specific fragments (133 and $320 \mathrm{bp}$ in length) visualized by ethidium bromide on 1\% agarose gel under UV light. The housekeeping gene, G3PDH, was included with each individual PCR run. The primers used were: $5^{\prime}$-ACC ACA GTC CAT GCC ATC AC-3' and $5^{\prime}$-TCC ACC ACC CTG TTG CTG TA-3' (Clontech Laboratories, Palo Alto, CA, USA).

PCR products were visualized by either electrophoresis in $8 \%$ polyacrylamide gels or $1.0 \%$ agarose gels containing $15 \mu \mathrm{l}$ ethidium bromide at a voltage of 200 volts for $1 \cdot 5 \mathrm{~h}$. Polyacrylamide gels were dried and exposed to a phosphor-based computerized radioactive image analyzer (Molecular Imager, Bio-Rad Laboratories, Hercules, CA, USA). The intensity of radioactivity in bands of the predicted molecular weight (signal intensity) was measured, subtracting the background obtained using a control sample from which the reverse transcriptase had been omitted (to detect any contamination of samples and buffers with cDNA).

\section{$D N A$ purification and separation}

DNA from T/I cells was prepared using the method of Tilly and Hsueh (1993) with some modifications. One hundred nanograms DNA were loaded in each well of the gel. Samples were run on a $1.5 \%$ agarose gel containing $15 \mu \mathrm{l}$ ethidium bromide at a voltage of 200 volts for $1.5 \mathrm{~h}$, and DNA fragments were visualized under UV light. A $1 \mathrm{~kb}$ DNA ladder marker (Gibco-BRL) was run simultaneously with the samples as an indicator of the band size of DNA fragments.

\section{Data analysis}

Due to the arbitrary units of signal intensity in which the raw data were obtained, data were expressed as a fold change in signal intensity relative to control. Results were plotted as the mean results ( \pm s.E.M.) from a minimum of three independent experiments. These results were subjected to analysis of variance, and significant effects of test treatments were determined at the $P<0 \cdot 05$ level by the least significant difference test.

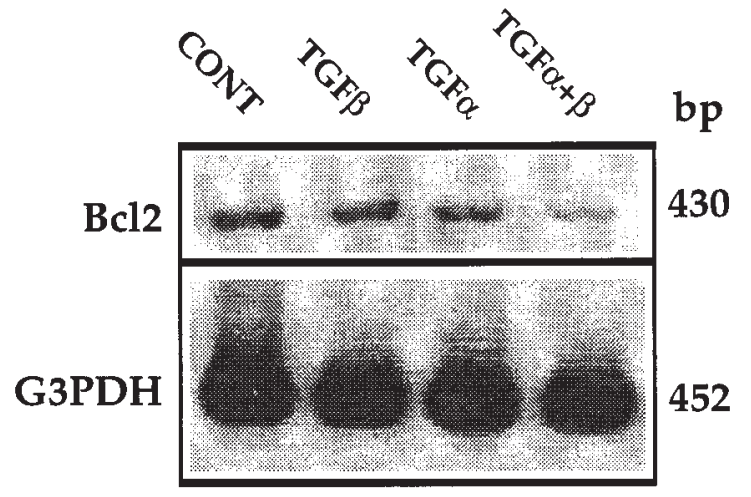

Figure 1 Regulation of bcl-2 mRNA levels in rat T/l cells by TGF $\alpha$ and TGF $\beta$. T/l cells were treated with TGF $\alpha(10 \mathrm{ng} / \mathrm{ml})$ and/or TGF $\beta(10 \mathrm{ng} / \mathrm{ml})$ for $10 \mathrm{~h}$. Bcl-2 and G3PDH PCR products were generated from cDNA prepared from total RNA. Aliquots of each PCR reaction were analyzed by polyacrylamide gel electrophoresis and autoradiography. CONT, control.

\section{Results}

The expression of bcl-2 in T/I cells cultured under control conditions was analyzed by PCR (Fig. 1). A specific PCR product for bcl-2 (430 bp) was amplified from cDNA isolated from T/I cells. Levels of mRNA for bcl-2 were unchanged following treatment of T/I cells with TGF $\alpha$ or TGF $\beta$ for $10 \mathrm{~h}$. The level of bcl-2 mRNA was decreased significantly compared with the control level following treatment of cells with TGF $\alpha$ together with TGF $\beta$ (Fig. 1). TGF $\alpha$ plus TGF $\beta$ decreased bcl-2 mRNA levels in $\mathrm{T} / \mathrm{I}$ cells within $3 \mathrm{~h}$ and this was followed by a progressive decline to $10 \%$ of control levels after $24 \mathrm{~h}$ of treatment (Fig. 2A,B). The expression of ICE in T/I cells was also analyzed by PCR (Fig. 3). A specific PCR product for ICE (453 bp) was amplified. Treatment of T/I cells with TGF $\alpha$ or TGF $\beta$ for $10 \mathrm{~h}$ did not influence the level of ICE mRNA appreciably. TGF $\alpha$ plus TGF $\beta$ caused a progressive increase in ICE mRNA reaching levels 2 - and 3 -fold higher than controls $(P<0 \cdot 005)$ after 5 and 7 h respectively (Fig. 4A,B). DNA was extracted from untreated T/I cells and from cells treated with TGF $\alpha$, TGF $\beta$, or TGF $\alpha$ plus TGF $\beta$ for $10 \mathrm{~h}$, and analyzed by gel electrophoresis. DNA was analyzed for fragmentation at 2, 3, 5, 10 and $24 \mathrm{~h}$ of treatment with TGF $\alpha$ plus TGF $\beta$. There was no evidence of fragmentation at 2 and $3 \mathrm{~h}$. The earliest time point at which a DNA ladder was detected was $5 \mathrm{~h}$; this was more pronounced at $10 \mathrm{~h}$ and $24 \mathrm{~h}$. As shown in Fig. 5, the DNA in control cells and cells treated with TGF $\alpha$ or TGF $\beta$ remained intact. The DNA extracted from cells treated with TGF $\alpha$ plus TGF $\beta$ was cleaved into fragments that were multiples of 180-300 bp in length.

\section{Discussion}

In this study we have shown that TGF $\alpha$ plus TGF $\beta$ regulates bcl-2 and ICE apoptotic gene expression in T/I 


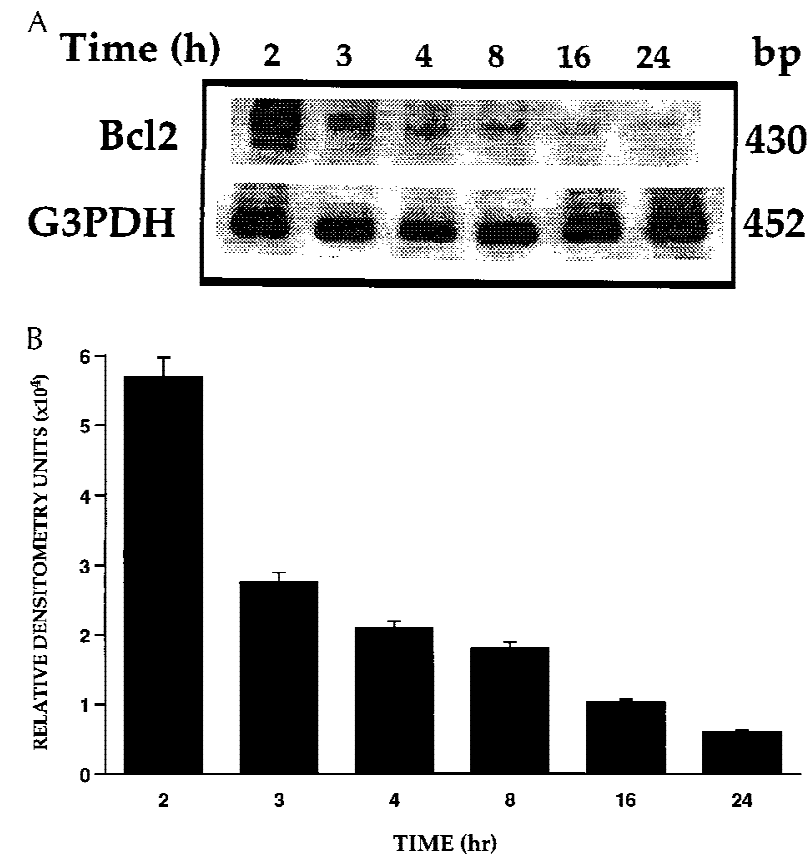

Figure 2 Time course $(2-24 \mathrm{~h})$ of effect of TGF $\alpha(10 \mathrm{ng} / \mathrm{ml})$ plus TGF $\beta(10 \mathrm{ng} / \mathrm{ml})$ on bcl-2 mRNA levels in T/l cells. Bcl-2 and G3PDH PCR products were obtained from cDNA prepared from total T/I cell RNA. Aliquots of each reaction were analyzed by polyacrylamide gel electrophoresis and radioautography (A). The intensity of the bands was measured using a phosphor-based computerized radioactive image analyzer (B).

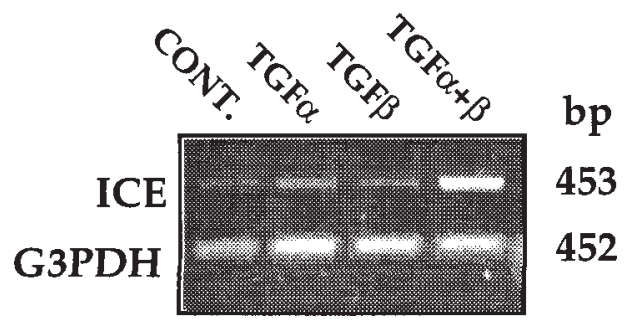

Figure 3 Regulation of ICE mRNA levels in rat T/I cells by TGF $\alpha$ and TGF $\beta$. T/I cells were treated with TGF $\alpha(10 \mathrm{ng} / \mathrm{ml})$ and/or TGF $\beta(10 \mathrm{ng} / \mathrm{ml})$ for $10 \mathrm{~h}$. ICE and G3PDH PCR products were obtained from cDNA prepared from total RNA. Aliquots of each PCR reaction were run on $1.5 \%$ agarose gels containing $15 \mu \mathrm{l}$ ethidium bromide and were visualized under UV light. CONT., control.

cells. Treatment with TGF $\alpha$ plus TGF $\beta$ caused a decrease in the level of bcl-2 below that in control cultures. This down-regulation of the 'survival' gene was accompanied by the simultaneous up-regulation of the 'death' gene, ICE. Treatment of T/I cells with TGF $\alpha$ plus TGF $\beta$, therefore, disturbed the balance between bcl-2 and ICE that existed in control cells and generated conditions that could cause their demise. TGF $\alpha$ plus TGF $\beta$ induced a significant reduction in bcl-2 mRNA levels after $3 \mathrm{~h}$ of treatment and a 2-fold increase in ICE mRNA after

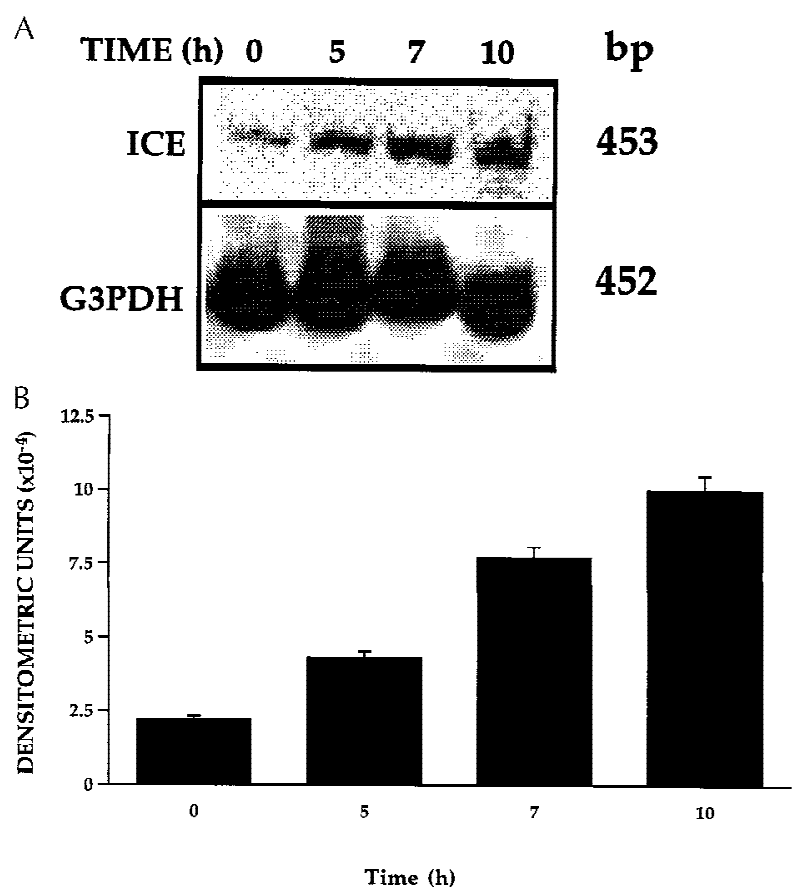

Figure 4 Time course $(0-10 \mathrm{~h})$ of the effect of TGF $\alpha(10 \mathrm{ng} / \mathrm{ml})$ plus TGF $\beta(10 \mathrm{ng} / \mathrm{ml})$ on ICE mRNA levels in T/I cells. ICE and G3PDH PCR products were obtained from cDNA prepared from total T/I cell RNA. Aliquots of each reaction were analyzed by polyacrylamide gel electrophoresis and radioautography (A). The intensity of the bands was measured using a phosphor-based computerized radioactive image analyzer (B).

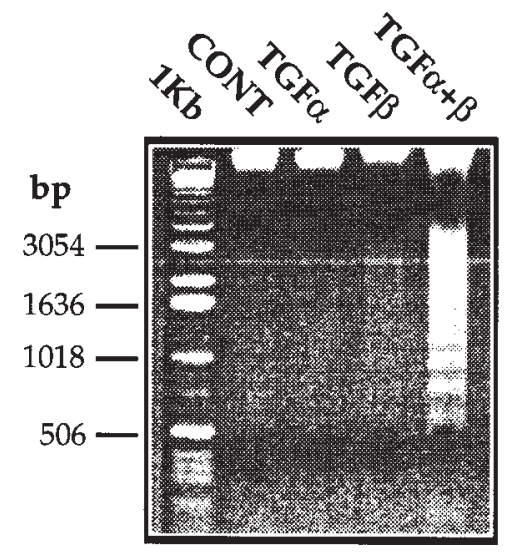

Figure 5 Analysis of DNA fragmentation in T/I cells treated for $10 \mathrm{~h}$ with TGF $\alpha(10 \mathrm{ng} / \mathrm{ml})$ and/or TGF $\beta(10 \mathrm{ng} / \mathrm{ml})$. DNA was extracted and analyzed by gel electrophoresis. DNA fragmentation into pieces that were multiples of $180-300 \mathrm{bp}$ in length was observed only in cells treated with TGF $\alpha$ plus TGF $\beta .1 \mathrm{~Kb}, 1 \mathrm{~kb}$ DNA ladder marker; CONT, control.

$5 \mathrm{~h}$. After $10 \mathrm{~h}$ of treatment with TGF $\alpha$ plus TGF $\beta$, internucleosomal DNA cleavage into fragments that were multiples of 180-300 in length was observed. 
Consequently the disruption of the balance between bcl-2 and ICE preceded the morphological manifestation of apoptosis, i.e. DNA fragmentation.

The expression of bcl-2 gene as well as other members of the bcl-2 family, bax and bcl-x, has been demonstrated in ovaries of immature rats and in isolated antral follicles (Tilly et al. 1995). In the latter study, immature rats were treated with equine chorionic gonadotropin to rescue follicles from atresia and promote the growth of a cohort of healthy follicles. Levels of bcl-2 and bcl-x in whole ovaries from treated animals were not significantly different from controls, whereas there was a significant reduction in the level of bax. Extensive DNA breakdown was detected in situ in granulosa cells of atretic antral follicles in ovaries of untreated animals, whereas thecal cells remained healthy (Tilly et al. 1995). On the basis of the data that we have presented, we anticipate that, during the later stages of atresia characterized by thecal cell elimination (Palumbo \& Yeh 1994, Logothetopoulos et al. 1995), a reduction in the level of bcl-2 gene expression would be observed.

$\mathrm{T} / \mathrm{I}$ cells are the only cells that have been identified in which there is a requirement for both TGF $\alpha$ plus TGF $\beta$ for regulation of bcl-2 and/or ICE and for the induction of apoptosis. Nevertheless, both of these growth factors have been implicated in the regulation of apoptosis. TGF $\beta$ has been identified as either an enhancer or an inhibitor of apoptosis in liver (Bayly et al. 1994), the immune system (Lomo et al. 1995) and mammary gland (Warri et al. 1993). Epidermal growth factor or TGF $\alpha$ protect rat granulosa cells from undergoing apoptosis (Tilly et al. 1992b) whereas they promote apoptosis in hepatocytes (Piacentini et al. 1991). Furthermore, TGF $\beta$ has been shown to down-regulate bcl-2 gene expression in M1 myeloid leukemia cells, a system in which it also induces apoptosis (Selvakumaran et al. 1994).

Apoptosis is a process that involves disruption of the cellular architecture that requires the involvement of proteases. ICE is a cysteine protease and its overexpression in various cell types has been implicated in cell death (Kumar 1995, Kumar \& Harvey 1995). Gonadotropinpromoted follicular survival has been shown to be associated with reduced ovarian expression of two ced-3 family members (CPP32, Ich-1), whereas no changes were observed in the expression of ICE (Flaws et al. 1995).

All cells generate free radicals during normal metabolism and can cause cell damage by the peroxidation of membrane lipids (Hockenberg 1995, Korsmeyer et al. 1995). Recently, we have shown that the ability of TGFa plus TGF $\beta$ to cause death of T/I cells by an apoptotic mechanism was blocked by the reducing agent $\mathrm{N}$-acetylL-cysteine, which is known to bind free radicals (Foghi et al. 1996b). This suggested that the action of free radicals was necessary for the induction of apoptosis in T/I cells. Bcl-2 acts as an antioxidant to protect cells from damage caused by free radicals. Therefore, we suggest that the combined action of TGF $\alpha$ and TGF $\beta$ on T/I cells that results in a decrease in the levels of bcl-2 expression (and possibly other members of the bcl-2 family) increases oxidative stress within the cells and causes their demise. Tilly \& Tilly (1995) have also shown that inhibitors of oxidative stress have the same effect as follicle-stimulating hormone in suppressing apoptosis in cultured rat follicles. On the basis of these studies, it was proposed that members of the bcl-2 gene family may be regulators of reductionoxidation pathways in granulosa cells, and thereby determine the fate of developing follicles-i.e. growth to the preovulatory stage or atresia.

Studies on C. elegans have shown that ced- $9 / \mathrm{bcl}-2$ is only necessary for survival when the suicide gene ced-3/ ICE is functional (Linette et al. 1995). This suggests that bcl-2 acts by preventing the actions of ICE. This hypothesis has been tested in different mammalian systems and, indeed, it has been shown that overexpression of bcl-2 prolongs the survival process by inhibiting ICE activity (Knudson et al. 1995, Kuida et al. 1995). Overexpression of ICE, on the other hand, causes programmed cell death in many cell types (Kuida et al. 1995), consistent with the notion that bcl-2 and ICE have opposing actions in regulating the balance between cell survival and cell death. The temporal changes in the levels of bcl-2 and ICE mRNA, induced by TGF $\alpha$ plus TGF $\beta$ in T/I cells in vitro, strongly suggest that these gene products are involved in the apoptotic pathway and the elimination of these cells.

\section{References}

Barinaga M 1994 Science 263 754-756.

Bayly AC, Roberts RA \& Dive C 1994 Journal of Cell Biology 125 197-203.

Bendell JJ \& Dorrington J 1988 Endocrinology 123 941-948.

Byskov AG 1978 In The Vertebrate Ovary, pp 533-562. Ed RE Jones. New York: Plenum Press.

Chomczynski P \& Sacchi N 1987 Single step method of RNA isolation by acid guanidinium thiocyanate-phenol-chloroform extraction. Analytical Biochemistry 162 156-159.

Flaws JA, Kugu K, Trbovich AM, DeSanti A, Tilly KI, Hirshfield AN \& Tilly JL 1995 Endocrinology 136 5042-5053.

Foghi A, Teerds KJ, Van der Donk H \& Dorrington J 1996 a Journal of Endocrinology 153 169-178.

Foghi A, Ravandi A, Kuksis A \& Dorrington J 19966 Canadian Fertility and Andrology Society Meeting Final Program and Abstract Book PF12 48.

Hengartner MO \& Horvitz HR 1994 Current Opinion in Genetics and Development 4 581-586.

Hirshfield AN 1991 International Review of Cytology 124 43-101.

Hockenbery DM 1995 BioEssays 17 631-638.

Hockenbery DM, Oltvai ZN, Yin X-M, Milliman CL \& Korsmeyer SJ 1993 Cell 75 241-251.

Hughes FM Jr \& Gorospe WC 1991 Endocrinology 129 2415-2422.

Knudson CM, Tong KSK, Tortellotte WG, Brown GA \& Korsmeyer SJ 1995 Science 270 96-98.

Korsmeyer SJ, Yin XM, Oltvai ZN, Vies-Novak DJ \& Linette GP 1995 Biochimica et Biophysica Acta 1271 63-66.

Kuida K, Lippke JA, Ku G, Harding MW, Livingston DJ, Su MSS \& Flavell RA 1995 Science 267 2000-2002. 
Kumar S 1995 Trends in Pharmacological Science 20 198-202.

Kumar S \& Harvey NL 1995 Federation of European Biochemical Societies 375 169-173.

Li P, Allen H, Banerjee S, Franklin S, Herzog L, Johnston C, McDowell J, Paskind M, Rodman L, Salfeld J, Town E, Tracy D, Wardwell S, Wei FY, Wong W, Kamen R \& Seshadri T 1995 Cell 80 401-411.

Linette GP, Hess JL, Sentman CL \& Korsmeyer SJ 1995 Blood 86 $1255-1260$.

Lobb DK, Skinner MK \& Dorrington JH 1988 Molecular and Cellular Endocrinology 55 209-217.

Logothetopoulos J, Dorrington J, Baily D \& Stratis M 1995 Anatomical Record 243 37-48.

Lomo J, Blomhoff HK, Beiske K, Stokke T \& Smeland EB 1995 Journal of Immunology 154 1634-1643.

Palumbo A \& Yeh J 1994 Biology of Reproduction 51 888-895.

Piacentini M, Autuori F, Dini L, Farrace MG, Ghibelli L, Piredda L \& Fesus L 1991 Cell Tissue Research 4263 227-235.

Schwartz LM \& Osborne BA 1994 BioEssays 16 387-389.

Selvakumaran M, Reed JC, Liebermann D \& Hoffman B 1994 Blood 84 1036-1042.
Skinner MK, Lobb D \& Dorrington JH 1987 Endocrinology 121 1892-1899.

Tao W, Teh SJ, Melhado I, Jirik F, Korsmeyer SJ \& Teh HS 1994 Journal of Experimental Medicine 179 145-153.

Tilly JL \& Hsueh AJW 1993 Journal of Cell Physiology 154 519-526.

Tilly JL \& Tilly KI 1995 Endocrinology 136 242-252.

Tilly JL, Kowalski KI, Johnson AL \& Hsueh AJW 1991 Endocrinology 129 2799-2801.

Tilly JL, Kowalski KI, Schomberg DW \& Hsueh AJW 1992a Endocrinology 131 1670-1676.

Tilly JL, Billig H, Kowalski KI \& Hsueh AJW $1992 b$ Molecular Endocrinology 6 1942-1950.

Tilly JL, Tilly KI, Kenton ML \& Johnson AL 1995 Endocrinology 136 232-241.

Warri AM, Huovinen RL, Laine AM, Martikainen PM \& Harkonen PL 1993 Journal of the National Cancer Institute 85 1412-1418.

Received 19 December 1996

Revised manuscript received 4 December 1997 Accepted 11 December 1997 